\title{
Kemampuan Literasi Matematis Siswa Pada Model Pembelajaran Quantum Teaching dalam Materi Teorema Pythagoras Kelas VIII SMPN 1 Jagoi Babang
}

\author{
Nur Gustika $^{1}$, Rosmaiyadi ${ }^{2}$, Buyung $^{3}$ \\ STKIP Singkawang, Singkawang, Indonesia \\ nur9u571k4@gmail.com ${ }^{1, *)}$, rosmaiyadialong@gmail.com², 21.buyung@gmail.com ${ }^{3}$ \\ ${ }^{*}$ Corresponding author
}

\section{Kata Kunci :}

Kemampuan Literasi

Matematis; Quantum

Teaching; Teorema

Pythagoras; Motivasi Belajar

\begin{abstract}
ABSTRAK
Kemampuan literasi matematis siswa berperan penting dalam pembelajaran matematika. Penelitian ini bertujuan untuk meningkatkan kemampuan literasi matematis siswa dengan menggunakan model pembelajaran quantum teaching. Metode penelitian yang digunakan adalah metode eksperimen. Sampel penelitian berjumlah 25 orang untuk kelas eksperimen dan 22 orang untuk kelas kontrol. Instrumen penelitian menggunakan tes kemampuan literasi matematis siswa dan angket motivasi belajar siswa. Hasil penelitian menunjukkan bahwa (1) terdapat peningkatan kemampuan literasi matematis siswa antara kelas yang menggunakan model pembelajaran quantum teaching dan kelas yang menggunakan model pembelajaran langsung dengan nilai $t_{\text {hitung }}=5,43>t_{\text {tabel }}=1,68$, (2) Kemampuan literasi matematis siswa mencapai ketuntasan individu dengan nilai $t_{\text {hitung }}=10,34>t_{\text {tabel }}=1,71$ bahwa rata-rata mencapai $K K M \geq 65$, selanjutnya untuk ketuntasan klasikal yaitu $Z_{\text {hitung }}=3,33 \geq Z_{\text {tabel }}=1,64$ disimpulkan bahwa ketuntasan klasikal siswa mencapai $70 \%$, dan (3) Hasil rata-rata motivasi belajar siswa diperoleh sebesar 59,71 dengan kategori baik.
\end{abstract}

\section{PENDAHULUAN}

Matematika merupakan disiplin ilmu yang mempunyai sifat khas, kekhasan itu berkenaan dengan ideide atau konsep-konsep abstrak yang tersusun secara hirarkis, Mata pelajaran matematika perlu diberikan kepada semua peserta didik mulai dari sekolah dasar, untuk membekali peserta didik dengan kemampuan berpikir logis, analitis, sistematis, kritis, inovatif dan kreatif, serta kemampuan bekerjasama menurut (Rosmaiyadi, 2017). Matematika merupakan ilmu yang mendasari perkembangan teknologi modern, mempunyai peranan penting dalam berbagai disiplin ilmu dan memajukan daya pikir manusia (Sari, 2016). Matematika adalah suatu alat untuk mengembangkan cara berfikir manusia yang sangat diperlukan dalam kehidupan. Siswa dikatakan berhasil belajar matematika apabila mampu mancapai tujuan matematika yang telah ditetapkan. pengetahuan matematika akan diperoleh siswa melalui proses belajar mengajar Menurut (Pratiwi, 2016). Materi dalam matematika saling terkait antara satu dengan yang lain, selain itu matematika juga tidak bisa terpisah dari disiplin ilmu lain dan masalah dalam kehidupan sehari-hari. 


\section{VARIABEL $8 \begin{aligned} & \text { Variabel Vol. } 2 \text { No. } 2 \\ & \text { (October 2019). Page: 46-55 }\end{aligned}$}

Matematika mempunyai arti penting dalam membantu manusia menyelesaikan masalah pada kehidupan sehari-hari. Konsep-konsep pada ilmu matematika dapat diterapkan untuk memecahkan masalah yang sedang dihadapi. Pembelajaran matematika di kelas tidak hanya menitik beratkan pada penguasaan materi untuk menyelesaikan masalah secara matematis. Tetapi juga membuat siswa lebih memahami konsep pada ilmu matematika itu sendiri dan membuat siswa lebih mengenal permasalahan-permasalahan dalam kehidupan sehari-hari yang dapat dipecahkan dengan pengetahuan matematika yang diperoleh siswa disekolah. Namun pada kenyataannya, kini siswa sering mengalami kesulitan dalam suatu soal matematika yang berhubungan dengan kehidupan sehari-hari (Nola, 2017).

Terdapat lima kompetensi dalam pembelajaran matematika, yaitu: pemecahan masalah matematis (mathematical problem solving), komunikasi matematis (mathematical communication), penalaran matematis (mathematical reasoning), matematis (mathematical reasoning), koneksi matematis (mathematical connection), dan representasi matematis (mathematical representation) menurut NCTM (Yunus \& dkk, 2017). Gabungan kelima kompetensi tersebut sangat diperlukan untuk kehidupan siswa agar dapat mempergunakan ilmu matematika dalam kehidupan sehari-hari. Kemampuan yang mencakup kelima kompetensi tersebut adalah kemampuan literasi matematis. Kemampuan literasi matematis dianggap sebagai salah satu komponen penting yang dibutuhkan siswa untuk dapat berhasil memecahkan masalah dalam kehidupan sehari-hari. Apabila dicermati, tujuan mata pelajaran matematika menurut Standar Isi (SI) menunjukkan bahwa kurikulum yang disusun sudah memperhatikan aspek literasi matematika (Buyung, 2018).

Kemampuan literasi matematis adalah menafsirkan matematika dalam berbagai konteks, termasuk didalamnya bernalar secara matematis dan menggunakan konsep, prosedur, fakta dan alat matematika dalam menjelaskan suatu fenomena (OECD, 2013a). Sejalan dengan Johar (2012) mengemukakan bahwa literasi atau melek matematika merupakan kemampuan individu merumuskan, menggunakan, dan menafsirkan matematika dalam berbagai konteks. Sedangkan menurut Siti (2018) Literasi matematika membantu seseorang untuk memahami peran atau kegunaan matematika di dalam kehidupan sehari-hari sekaligus menggunakannya untuk membuat keputusan-keputusan yang tepat sebagai warga negara yang membangun, peduli dan berpikir. Dari uraian sebelumnya dapat disimpulkan bahwa kemampuan literasi adalah kemampuan seseorang untuk merumuskan, menerapkan dan menafsirkan matematika dalam berbagai kontek termasuk kemampuan melakukann penalaran secara matematis dan menerapkan konsep, prosedur, fakta, sebagai alat untuk menggambarkan, menjelaskan atau mempekirakan suatu penomena atau kejadian.

Berdasarkan studi PISA (Programme for International Student Assessment), yaitu studi tentang penilaian siswa tingkat internasional tiap 3 tahun sekali terhadap kemampuan siswa berusia 15 tahun dalam membaca, matematika, dan sains, hasil yang dicapai siswa Indonesia jauh dari memuaskan. Pada penyelenggaraan PISA tahun 2000, Indonesia hanya mampu menempati posisi 39 dari 41 negara untuk bidang matematika dengan skor 367, jauh di bawah skor rata-rata yaitu 500. Pada PISA 2003, Indonesia berada pada ranking 38 dari 40 negara dengan skor 361. Pada PISA 2006, Indonesia berada pada urutan 50 dari 57 negara dengan skor 391. Pada pelaksanaan PISA 2009, Indonesia meraih posisi 61 dari 65 negara dengan skor 371. Sementara pada PISA 2012, Indonesia hanya mampu mencapai posisi 64 dari 65 negara dengan skor 375 (OECD, 2013).

Menurut Diyarko (2016) Banyak faktor yang menyebabkan rendahnya kesulitan siswa dalam menyelesaikan soal literasi matematika, selain tidak adanya pembiasaan dari guru dengan soal-soal literasi matematika, faktor metode dan media yang digunakan kurang mendukung pembelajaran. Menurut Penelitian Rusmining (2014) menunjukkan bahwa kemampuan literasi matematika pada siswa yang diteliti tergolong rendah yaitu pada level di bawah 3. Kemampuan membuat model matematika, memberikan alasan dan berargumen serta menemukan strategi pemecahan masalah siswa tergolong rendah. Rendahnya kemampuan tersebut karena guru lebih banyak memberikan penjelasan materi dan minim sekali siswa membangun pengetahuannya. Sedangkan menurut (Khotimah, 2018) menyatakan kemampuan literasi matematis rendah dalam proses pembelajaran siswa hanya 
mendengarkan apa yang guru sampaikan dan sangat jarang melakukan tanya jawab untuk mengecek pemahaman siswa sehingga pembelajaran hanya berpusat pada guru menyebabkan siswa kurang aktif dalam melakukan proses belajar mengajar di kelas, siswa hanya menerima pembelajaran secara pasif, dan kurang mengerti dengan materi yang disampaikan,sehingga siswa merasa bingung, bosan dan tidak ada semangat dalam mengikuti pembelajaran yang sedang berlangsung.

Dengan demikian literasi matematika membantu seseorang untuk mengenal peran matematika dalam dunia dan membuat pertimbangan maupun keputusan yang dibutuhkan sebagai warga negara. Di abad modern ini, semua orang perlu memiliki literasi matematika yang dapat digunakan saat menghadapi berbagai permasalahan. Hal ini dikarenakan literasi matematika sangat penting bagi semua orang dan perserta didik di sekolah.

Berdasarkan hasil pengamatan langsung di sekolah SMPN 1 Jagoi Babang guru di kelas VIII diperoleh berbagai hal pada proses pembelajaran matematika. Fakta yang ditemukan diantaranya siswa kurang memahami materi yang guru sampaikan. Sehingga siswa belum sepenuhnya memiliki kemampuan literasi terutama pada tahap penalaran untuk memecahkan masalah berkaitan dengan kehidupan sehari-hari yang mereka hadapi, menyebabkan nilai rata-rata ulangan siswa banyak yang dibawah $\mathrm{KKM}=65$. Sejalan dengan penelitian Buyung (2017) yang menyatakan bahwa siswa belum sepenuhnya memiliki kemampuan literasi terutama pada tahap pemodelan dan penelaran untuk memecahkan masalah berkaitan dengan kehidupan sehari-hari, menyebabkan nilai rata-rata ulangan siswa banyak yang dibawah KKM. Tersebut ditunjukkan dari lemahnya kemampuan siswa dalam mencari alternatif pemecahan masalah jika menemukan kesulitan dalam materi geometri.

Pembelajaran geometri sangat bermanfaat bagi siswa, sebagai dasar untuk menguasai, mempelajari dan memahami materi matematika yang lain maupun konsep bagun datar di jenjang pendidikan. Siswa di sekolah menengah pada umumnya mengalami kesulitan dalam mempelajarinya. Kesulitan siswa tersebut dapat berdampak pada rendahnya pemahaman fakta, konsep, aturan dan prosedur geometri selanjutnya yang lebih kompleks, salah satu yang sering dianggap sulit, salah satunya adalah pada materi teorema pythagoras.

Teorema Pythagoras adalah kuadrat panjang sisi miring segitiga siku-siku sama dengan jumlah kuadrat sisi-sisi lainnya. Mengambil materi ini, karena banyaknya masalah-masalah dalam kehidupan sehari-hari yang dapat dipecahkan secara sederhana dalam bahasa simbol dalam geometri membuatnya penting untuk dipelajari, bahkan bukan hanya sekedar dipelajari namun juga dipahami. Namun teorema pythagoras yang seharusnya penting ini justru memberikan masalah bagi siswa.

Sementara itu, teorema pythagoras merupakan bagian dari materi matematika kelas VIII semester ganjil yang menuntut pemikiran siswa untuk menemukan konsep secara teliti dalam menyelesaikan soal-soal yang berkaitan dengan teorema Pythagoras dan guru harus memberikann motivasi. Motivasi belajar adalah serangkayan usaha untuk menyediakan kondisi-kondisi serta dorongan tertentu, sehingga seseorang mau dan ingin melakukan sesuatu menurut Sadirman (2014). Sedangkan menurut Silvia (2015) motivasi belajar adalah seluruh daya penggerak di dalam diri siswa yang menimbulkan kegiatan belajar menjamin kelangsungan dan memberikan arah pada kegiatan belajar sehingga tujuan yang dikehendaki dapat tercapai. Menurut Luvy (2016) bahwa motivasi adalah perubahan energi dalam diri seseorang yang ditandai dengan munculnya feeling dan didahului dengan tanggapan terhadap adanya tujuan. Dari uraian sebelumnya dapat disimpulkan bahwa motivasi belajar adalah dorongan tertentu untuk seseorang dapat mencapai tujuan yang diinginkan.

Selain itu model pembelajaran yang dapat dijadikan alternatif untuk mengatasi kemampuan literasi dan motivasi adalah pembelajaran quantum teaching. Pembelajaran quantum teaching merupakan salah satu model pembelajaran yang bertujuan untuk memberikan cara bagi peserta didik untuk membangun dan megembangkan pemikirannya. Quantum Teaching adalah penggubahan belajar yang meriah, dengan segala nuansa dan Quantum Teaching juga menyertakan segala kaitan, interaksi, dan perbedaan yang memaksimalkan momen belajar. Dalam pembelajaran Quantum Teaching 
menjelaskan bahwa bawalah dunia mereka ke dunia kita dan antarkan dunia kita kedunia mereka. Adapun kelebihan-kelebihan model pembelajaran Quantum Teaching menurut Umi (2012) sebagai berikut: Peserta didik lebih mudah memahami pelajaran siswa terlibat langsung dalam pembelajaran; Menumbuhkan dan menimbulkan antusiasme siswa; Menciptakan tingkah laku dan sikap kepercayaan dalam diri siswa; Strategi Quantum Teaching menumbuhkan adanya kerjasama antara siswa yang satu dengan siswa yang lain.

Kelebihan model Quantum Teaching sebagai berikut, Selalu berpusat pada apa yang masuk akal bagi siswa; Menumbuhkan dan menimbulkan antusiasme siswa; Adanya kerjasama; Menawarkan ide dan proses cemerlang dalam bentuk yang enak dipahami siswa; Menciptakan tingkah laku dan sikap kepercayaan dalam diri sendiri; Belajar terasa menyenangkan; Ketenangan psikologi; Adanya kebebasan dalam berekspresi Sriwijaya (2019). Kelebihan Quantum Teaching sebagai berikut: Selalu berpusat pada apa yang masuk akal siswa; Menumbuhkan dan menimbulkan antusiasme siswa; Adanya kerjasama; Menawarkan ide dan proses cemerlang dalam bentuk yang enak dipahami siswa; Menciptakan tingkah laku dan sikap kepercayaan dalam diri sendiri; Belajar terasa menyenangkan; Ketenangan psikologi; Motivasi dari dalam; Adanya kebebasan dalam berekspresi; Menumbuhkan idealisme, gairah dan cinta mengajar oleh guru menurut Wijiyanto (2012).

Menurut hasil penelitian Nilfitra (2016) setelah menerapkan model quantum teaching dapat mengalami peningkatan pencapaian motivasi belajar siswa sebesar $70,4 \%$ dengan kategori Baik. Menurut hasil penelitian Wiwin (2018) menyatakan model pembelajaran Quantum Teaching dapat peningkatan yakni $77,27 \%$. Dalam hal ini mencapai ketuntasan lebih dari $75 \%$ siswa yang mencapai KKM yaitu dengan presentase 77, 27\% atau 17 siswa dari 22 siswa. Sedangkan menurut hasil penelitian Susanti (2016) menyatakan model pembelajaran Quantum Teaching mengalami peningkatan, hal ini dapat dilihat pada peningkatan tiap siklus, pada siklus I dengan presentase 60,94\%. Sedangkan model pembelajaran Quantum Teaching siklus II mengalami peningkatan menjadi $70,83 \%$, dan siklus ke III mengalami peningkatan lagi menjadi 81,77\%. Kerelevanan dengan penelitian ini yakni sama-sama menggunakan model Quantum Teaching.

Berdasarkan penjelasan model pembelajaran Quantum Teaching di harapkan dapat meningkatkan hasil belajar karena model ini menggunakan prinsip sugesti yang pasti dan dapat mempengaruhi hasil belajar. Selain itu, model ini lebih menekankan kreativitas siswa dalam proses pembelajaran, siswa lebih aktif dalam proses pembelajaran, siswa dapat mengembangkan suatu teori atau pemahaman yang mereka miliki. Siswa dituntut lebih percaya diri untuk mengemukakan sebuah pendapat.

Berdasarkan pemaparan tentang kemampuan literasi matematis tersebut menunjukan bahwa kemampuan literasi matematis merupakan kemampuan yang penting untuk dikembangkan pada siswa sekolah menengah. Sehingga penulis ingin mengkaji lebih mendalam tentang kemampuan literasi matematis pada model pembelajaran quantum teaching dalam materi teorema Pythagoras kelas VIII SMPN 1 Jagoi Babang yang berada di perbatasan.

\section{METODE PENELITIAN}

Penelitian ini merupakan penelitian kuantitatif dengan metode eksperimen yang dilakukan pada dua kelas yaitu kelas VIII A dan kelas VIII B dengan sampel yang berjumlah 57 orang. Desain penelitian ini adalah True Ekperimental designs dengan bentuk pretest-posttest control group design yang dapat dilihat di Tabel 1.

Tabel 1. Pretest-Posttest Control Group Design

\begin{tabular}{lccl}
\hline \multicolumn{1}{c}{ Kelas } & Pre-test & Perlakuan & Post-test \\
\hline Eksperimen & $\mathrm{O}_{1}$ & $\mathrm{X}_{1}$ & $\mathrm{O}_{2}$ \\
Kontrol & $\mathrm{O}_{3}$ & $\mathrm{X}_{2}$ & $\mathrm{O}_{4}$ \\
\hline
\end{tabular}


Menurut sugiyono (2015) metode eksperimen adalah metode penelitian yang digunakan untuk mencari pengaruh perlakuan tertentu terhadap yang lain dalam kondisi yang terkendalikan. Populasi dalam penelitian ini adalah seluruh siswa kelas VIII SMPN 1 Jagoi Babang yang berjumlah 80 terdiri dari 3 kelas yaitu VIIIA, VIIIB, dan VIIIC. Teknik pengambilan sampel yang digunakan dalam penelitian ini adalah purposive sampling, yaitu mengambil dua kelas dari kelas VIII SMPN 1 Jagoi Babang tahun pelajaran 2018-2019. Untuk mengetahui peningkatan kemampuan literasi matematis menggunakan rumus $N$-Gain (Persamaan 1) dengan mengikuti kriteria pada Tabel 2.

$$
N \text {-Gain }=\frac{\text { Skor Posttest-skor pretest }}{\text { Skor maksimal ideal-Skor pretest }}
$$

Tabel 2. Kriteria Indeks $N$-Gain

\begin{tabular}{cc}
\hline Indeks $\boldsymbol{N}$-Gain & Kriteria \\
\hline $\mathrm{N}-\mathrm{g} \geq 0,7$ & Baik \\
$0.3<\mathrm{N}-\mathrm{g} \leq 0,7$ & Sedang \\
$\mathrm{N}-\mathrm{g} \leq 0,3$ & Rendah \\
\hline
\end{tabular}

Uji peningkatan kemampuan literasi matematis menggunakan uji-t independen, untuk mengetahui ketuntasan individual literasi matematis menggunakan uji t, uji ketuntasan klasikal menggunakan uji z, untuk mengetahui motivasi belajar siswa baik dengan menghitung persentase rata-rata jawaban siswa secara keseluruhan dengan menggunakan rumus pada Persamaan 2.

$$
\bar{P}_{T}=\frac{\Sigma \bar{p}_{\bar{i}}}{k} \times 100 \%
$$

Adapun kriteria motivasi belajar siswa dapat dilihat pada Tabel 3.

\begin{tabular}{|c|c|}
\hline Jumlah Persentase & Kategori \\
\hline $72 \%<\bar{P}_{T} \leq 96 \%$ & Sangat Baik \\
\hline $48 \%<\bar{P}_{T} \leq 71 \%$ & Baik \\
\hline $24 \%<\bar{P}_{T} \leq 47 \%$ & Cukup Baik \\
\hline $0 \%<\bar{P}_{T} \leq 23 \%$ & Rendah \\
\hline
\end{tabular}

Tabel 3. Kriteria Motivasi Belajar Siswa

\section{HASIL DAN PEMBAHASAN}

\section{Hasil}

1. Peningkatan Kemampuan Literasi Matematis

Hasil nilai pretest dan posttest untuk mencari perbedaan Peningkatan kemampuan literasi matematis kelas yang menggunakna model pembelajaran quantum teaching dan kelas yang menggunakan model pembelajaran langsung dengan cara menghitung nilai $N$-Gain. Data perhitungan $N$-Gain kelas eksperimen dan kelas kontrol dapat dilihat pada Tabel 4.

Tabel 4. Hasil Nilai Rata-Rata Pre-Test dan Post-Test

\begin{tabular}{cccc}
\hline \multirow{2}{*}{ Kelas } & \multicolumn{2}{c}{ Nilai rata-rata } & \\
\cline { 2 - 3 } & Pre-test & Post- test & N-Gain \\
\hline Eksperimen & 53,36 & 86,89 & 0,71 \\
Kontrol & 52,55 & 68,44 & 0,34 \\
\hline
\end{tabular}

Selanjutnya dilakukan Uji Normalitas Kelas Eksperimen dan Kelas Kontrol. Hasil uji normal dapat dilihat pada Tabel 5 . 


\section{VARIABEI Variabel Vol. 2 No. 2 (October 2019). Page: 46-55}

Tabel 5. Hasil Uji Normalitas Kelas Eksperimen dan Kontrol

\begin{tabular}{cccccc}
\hline Kelompok & Sampel & Rata-Rata & SD & $\boldsymbol{X}_{\text {hitung }}$ & $\boldsymbol{X}_{\text {tabel }}$ \\
\hline Eksperimen & 25 & 19,72 & 6,48 & 6,58 & 11,07 \\
Kontrol & 22 & 18,82 & 5,06 & 10,68 & 11,07 \\
\hline
\end{tabular}

Setelah dilakukan uji normalitas, selanjutnya menghitung rata-rata skor kelas eksperimen dan kelas kontrol. Hasil rata-rata dapat dilihat pada Gambar 1.

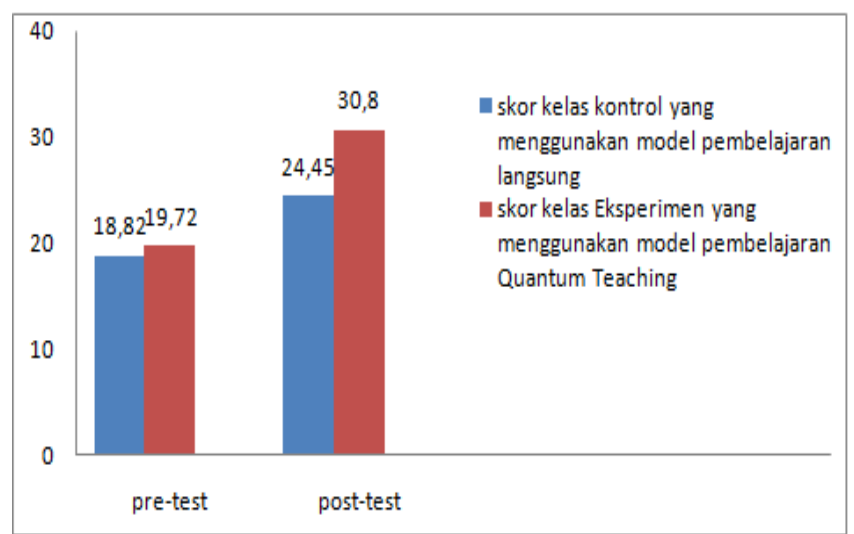

Gambar 1. Diagram Rata-Rata Skor Pretest Dan Posttest

Selajutnya dilakukan Uji-t independen. Hasil uji-t independen dapat dilihat pada Tabel 6.

Tabel 6. Hasil Uji-t Independen

\begin{tabular}{cccccc}
\hline Kelompok & Sampel & Rata-Rata & SD & $\boldsymbol{t}_{\text {hitung }}$ & $\boldsymbol{t}_{\text {tabel }}$ \\
\hline Eksperimen & 25 & 30,8 & 6,62 & \multirow{2}{*}{5,43} & \multirow{2}{*}{1,68} \\
Kontrol & 22 & 24,45 & 3,34 & & \\
\hline
\end{tabular}

Maka diperoleh bahwa $t_{\text {hitung }}=5,43>t_{\text {tabel }}=1,68$ sehingga $\mathrm{H}_{\mathrm{o}}$ ditolak dan $\mathrm{H}_{\mathrm{a}}$ diterima dengan taraf signifikan 5\% atau 0,05. Maka dapat disimpulkan bahwa terdapat perbedaan peningkatan kemampuan literasi matematis siswa kelas yang menggunakan model pembelajaran Quantum Teaching dan kelas yang menggunakan model pembelajaran langsung.

2. Ketuntasan Kemampuan Literasi Matematis Siswa

Untuk mengetahui rata-rata nilai Tes Kemampuan Literasi Matematis tersebut dilakukan dengan menghitung nilai $t$. Dari data diperolehan nilai tes kemampuan literasi matematis kelas yang menggunakan model pembelajaran quantum teaching dengan banyak siswa $(n)=25$, nilai rata-rata $(\bar{x})$ $=86,89$ dan simpangan baku $(s)=11,57$ maka diperoleh nilai $t_{\text {hitung }}=10,34$. Selanjutnya dibandingkan dengan harga $t_{\text {tabel }}$ taraf kesalahan 5\% sebesar 1,71. Karena $t_{\text {hitung }}>t_{\text {tabel }}$ atau 10,34 $>1,71$ ini berarti $\mathrm{H}_{\mathrm{o}}$ ditolak dan $\mathrm{H}_{\mathrm{a}}$ diterima. Jadi, kesimpulan yang diperoleh adalah rata-rata nilai Tes Kemampuan Literasi Matematis siswa yang menggunakan model pembelajaran quantum teaching telah mencapai $\mathrm{KKM}=65$.

Suatu kelas dikatakan tuntas belajarnya (ketuntasan klasikal) jika dalam kelas tersebut terdapat mencapai $=70 \%$ siswa yang telah tuntas belajarnya. Uji ini dilakukan untuk mengetahui apakah nilai Tes Kemampuan Literasi Matematis siswa yang mendapatkan minimal lebih dari atau sama dengan KKM mencapai 70\%. Dengan: $n=25 ; \mathrm{H}_{\mathrm{o}}=0,70$ dan Jadi diperoleh nilai $z_{\text {hitung }}=3,33$ dibandingkan $z_{\text {tabel }}=1,64$ dengan taraf kesalahan $5 \%$ atau 3,33 > 1,64, maka $\mathrm{H} 0$ ditolak dan $\mathrm{H}_{\mathrm{a}}$ diterima. Artinya, proporsi siswa yang mendapat nilai tes kemampuan literasi matematis lebih dari atau sama dengan $\mathrm{KKM}=65$ telah melampaui $70 \%$. 
3. Motivasi Belajar Siswa

Hasil perhitungan motivasi belajar siswa dapat dilihat pada Tabel 7.

Tabel 7. Hasil Angket Motivasi Belajar Siswa

\begin{tabular}{|c|c|c|c|c|c|c|c|c|}
\hline \multirow[t]{2}{*}{ No Pertanyaan } & \multicolumn{5}{|c|}{ jumlah tanggapan } & \multirow{2}{*}{$\begin{array}{l}\text { Jumlah } \\
\text { Skor }\end{array}$} & \multirow[t]{2}{*}{ Persentase } & \multirow{2}{*}{ Kriteria } \\
\hline & SS & $S$ & RG & TS & TST & & & \\
\hline 1 & 18 & 6 & 0 & 0 & 0 & 114 & 62,50 & Baik \\
\hline 2 & 5 & 3 & 16 & 0 & 0 & 85 & 50,35 & Baik \\
\hline 3 & 4 & 19 & 1 & 0 & 0 & 99 & 65,65 & Baik \\
\hline 4 & 7 & 17 & 0 & 0 & 0 & 103 & 58,68 & Baik \\
\hline 5 & 21 & 3 & 0 & 0 & 0 & 117 & 78,13 & Sangat baik \\
\hline 6 & 4 & 2 & 17 & 1 & 0 & 81 & 53,82 & Baik \\
\hline 7 & 7 & 17 & 0 & 0 & 0 & 103 & 58,68 & Baik \\
\hline 8 & 3 & 5 & 16 & 0 & 0 & 83 & 50,35 & Baik \\
\hline 9 & 14 & 10 & 0 & 0 & 0 & 110 & 51,39 & Baik \\
\hline 10 & 15 & 4 & 3 & 2 & 0 & 104 & 44,10 & Cukup Baik \\
\hline 11 & 8 & 16 & 0 & 0 & 0 & 104 & 55,56 & Baik \\
\hline 12 & 19 & 5 & 0 & 0 & 0 & 115 & 67,02 & Baik \\
\hline 13 & 10 & 14 & 0 & 0 & 0 & 106 & 51,39 & Baik \\
\hline 14 & 3 & 1 & 20 & 0 & 0 & 79 & 71,18 & Baik \\
\hline 15 & 6 & 18 & 0 & 0 & 0 & 102 & 62,50 & Baik \\
\hline 16 & 16 & 8 & 0 & 0 & 0 & 112 & 55,56 & Baik \\
\hline 17 & 5 & 3 & 16 & 0 & 0 & 85 & 50,35 & Baik \\
\hline 18 & 19 & 5 & 0 & 0 & 0 & 115 & 67,02 & Baik \\
\hline 19 & 5 & 2 & 17 & 0 & 0 & 84 & 55,21 & Baik \\
\hline 20 & 2 & 22 & 0 & 0 & 0 & 98 & 84,73 & Sangat Baik \\
\hline jumlah & & & & & & 2004 & 1194,17 & \\
\hline Rata-rata & & & & & & & 59,71 & Baik \\
\hline
\end{tabular}

Berdasarkann hasil perhitungan motivasi belajar siswa yang mencapai rata-rata 59,71 memberikan motivasi yang baik terhadap model pembelajaran Quantum Teaching pada materi teorema Pythgoras.

\section{Pembahasan}

Hasil kemampuan literasi matematis siswa menunjukan bahwa pembelajara matematika menggunakan model pembelajaran Quantum Teaching pada materi teorema pythagoras yang diterapkan di kelas VIII A SMPN 1 Jagoi Babang dapat meningkat secara signifikan. Ini dapat dilihat dari hasil pre-test dan post-test kemampuan literasi matematis siswa kelas eksperimen lebih tinggi dari pada hasil tes kemampuan literasi matematis siswa kelas kontrol. Hal ini terbukti pada pengujian hipotesis dengan perhitungan $N$-Gain diperoleh nilai rata-rata Gain kelas eksperimen $(0,71)$ kategori sedang sedangkan Gain kelas kontrol $(0,34)$ kategori sedang.

Dari hasil perhitungan data sesuai kriteria perhitungan homogenitas varians, maka varians skor data kelas eksperimen dan kelas kontrol homogen. Setelah data homogen maka selanjutnya perhitungan uji-t. Hasil perhitungan seperti yang tertera pada tabel sebelumnya maka diperoleh data uji-t untuk menentukan perbedaan peningkatan kelas eksperimen dengan menggunakan model pembelajaran quantum teaching dan pembelajaran dengan menggunakan model pembelajaran langsung terdapat perbedaan peningkatan yang signifikan antara kelas eksperimen dan kelas kontrol yaitu kemampuan literasi matematis siswa kelas eksperimen lebih tinggi dibandingkan kemampuan literasi matematis siswa kelas kontrol. Terdapat perbedaan peningkatan kemampuan literasi matematis siswa yang segnifikan setelah menerapkan model pembelajaran quantum teaching.

Dengan demikian bahwa model pembelajaran quantum teaching dapat meningkatkan kemampuan literasi matematis siswa. Hal ini sejalan dengan penelitian Wiwin (2015) menyatakan bahwa model pembelajaran Quantum Teaching dapat meningkatkan hasil belajar siswa, dibandingkan dengan model pembelajaran langsung. 
Hal ini dapat dilihat bahwa model pembelajaran quantum teaching dapat meningkatkan kemampuan literasi matematis siswa pada materi teorema pythagoras, karena model pembelajaran quantum teaching dapat membantu siswa lebih aktif dalam pembelajaran dan membantu siswa untuk berfikir lebih keras lagi dalam menghubungkan materi matematika dengan materi matematika lainnya. Hasil ini sejalan dengan penelitian yang dilakukan oleh Syahrida (2014: 149) bahwa hasil belajar siswa memggunakan model pembelajaran quantum teaching dapat meningkat dengan baik.

Kemudian dapat diketahui bahwa ketuntasan secara individual mencapai rata-rata dan ketuntasan secara klasikal mencapai 70\%. Hal ini menunjukkan bahwa kemampuan literasi matematis siswa mencapai Kriteria Ketuntasan Minimal (KKM) yaitu 65 secara individual maupun klasikal pada materi teorema Pythagoras yang diajarkan dengan menggunakan model pembelajaran quantum teaching.

Motivasi belajar siswa dilihat dari angket dengan beberapa indikator yaitu; (1) hasrat dan keinginan berhasil, (2) dorongan dan kebutuhan dalam belajar, (3) harapan dan cita-cita masa depan dan (4) berprestasi dalam belajar. Dapat diketahui rata-rata skor total motivasi belajar siswa yaitu 59,71 dengan kriteria motivasi belajar siswabaik. Sehingga dapat disimpulkan bahwa motivasi belajar siswa baik pada materi teorema Pythagoras dengan menggunakan model quantum teaching. Hal ini sejalan dengan teori belajar Gagne yang menyatakan bahwa delapan fase dalam belajar satu diantaranya adalah motivasi. Siswa yang belajar harus diberi motivasi untuk belajar dengan harapan bahwa belajar akan memperoleh hadiah. Selain itu, hal ini sejalan juga dengan hasil penelitian Nara (2014) mengungkapkan bahwa dari beberapa hasil penelitian menunjukan bahwa motivasi siswa merupakan faktor yang banyak memberikan pengaruh terhadap hasil belajar. Hal ini bearti semakin baiknya motivasi belajar maka semakin baik juga hasil belajar siswa, begitu juga sebaliknya, apabila hasil belajar siswa baik maka dapat diketahui bahwa mativasi belajar siswa tinggi.

Model pembelajaran quantum teaching merupakan satu diantara model yang dapat melatih kemampuan literasi matematis siswa dan membantu siswa lebih aktif dalam pembelajaran sehingga siswa termotivasi untuk belajar. Sebelum model pembelajaran quantum teaching diterapkan kemampuan literasi matematis siswa motivasi belajar siswa masih rendah. Selain itu, motivasi belajar siswa juga tergolong rendah. Setelah diterapkan model pembelajaran quantum teaching kategori kemampuan literasi matematis siswa meningkat.

\section{KESIMPULAN}

Berdasarkan hasil penelitian dan pembahasan diperoleh kesimpulan tentang kemampuan literasi matematis siswa pada model pembelajaran quantum teaching dalam materi teorema Pythagoras SMPN 1 Jagoi Babang. Kesimpulan tersebut dapat diuraikan sebagai berikut:

1. Terdapat perbedaan peningkatan kemampuan literasi matematis siswa antara kelas yang menggunakan model pembelajaran quantum teaching dan kelas yang menggunakan model pembelajaran langsung pada materi teorema Pythagoras dengan nilai $t_{\text {hitung }}=5,43>t_{\text {tabel }}=1,68$.

2. Kemampuan literasi matematis siswa mencapai Kriteria Ketuntasan Minimal secara individu dengan nilai $t_{\text {hitung }}=10,34>t_{\text {tabel }}=1,71$ bahwa rata-rata mencapai $\mathrm{KKM} \geq 65$ dan ketuntasan klasikal yaitu $Z_{\text {hitung }}=3,33 \geq Z_{\text {tabel }}=1,64$ bahwa ketuntasan klasikal siswa mencapai $70 \%$ setelah diterapkan model pembelajaran quantum teaching.

3. Motivasi belajar siswa baik setelah diterapkan model pembelajaran quantum teaching pada materi teorema Pythagoras dengan hasil rata-rata sebesar 59,71.

\section{DAFTAR PUSTAKA}

Buyung, B., \& Dwijanto, D. (2017). Analisis Kemampuan Literasi Matematis melalui Pembelajaran Inkuiri dengan Strategi Scaffolding. Unnes Journal of Mathematics Education Research, 6(1), 112-119. 
Buyung, B., \& Nirawati, R. (2018). Pengaruh Karakter Kerja Keras Terhadap Kemampuan Literasi Matematis Siswa Melalui Model Discovery Learning. JPMI (Jurnal Pendidikan Matematika Indonesia), 3(1), 21-25.

Diyarko, Budi. W. (2016). Analisis Kemampuan Literasi Matematika Ditinjau Dari Metakognisi Dalam Pembelajaran Inkuiri Berbantuan Lembar Kerja Mandiri Mailing Merge. Unnes Journal of Mathematics Education Research, 5(1),70-80.

Johar, R. (2015). "Domain Soal PISA untuk Literasi Matematika". Jurnal Pendidikan Matematika, 1(1), 30-41.

Khotimah, N., Utami, C., \& Prihatiningtyas, N. C. (2018). Penerapan Model Learning Cycle 7E Untuk Meningkatkan Kemampuan Literasi Matematis Siswa Kelas VIII Pada Materi Prisma. JPMI (Jurnal Pendidikan Matematika Indonesia), 3(1), 15-20.

Luvy. S. (2016). Pengaruh Motivasi Belajar Ditinjau Dari Latar Belakang Pilihan Jurusan Terhadap Kemampuan Berpikir Kritis Mahasiswa di STKIP Siliwangi Bandung. Jurnal pendidikan matematika, 1(1), 132-140.

Nara, H. Siregar. Eveline. (2014). Teori belajar dan Pembelajaran. Bogor: Ghalia Indonesia.

Nilfitra. (2016). Penerapan Model Pembelajaran Quantum Teaching dalam Meningkatkan Motivasi Belajar Siswa pada Materi Himpunan di Kelas VII SMP Negeri Sukajadi Pekanbaru.Skripsi. Tidak dipulikasikan.

Nola. N, Anton. P. (2016). Analisis Kesulitan Belajar Ditinjau Darikemampuan Koneksi Matematika Peserta Didik. http://ecampus.iainbatusangkar.ac.id/ojs/index.php/proceedings/article/viewFile/653/643. (diakses 11 januari 2018).

OECD. (2013). Draft PISA 2015 Assessment Framework. (Online). Tersedia. http://www.oecd.org/dataoecd/61/15/46241909. (diakses 3 febuari 2018).

OECD. (2013a). PISA 2012 Assessment and Analytical Framework: Mathematics, Reading, Science, Problem Solving, and Financial Literacy. OECD Publishing. http://dx.doi.org/10.1787/9789264190511-en. (diakses 24 maret 2019).

Pratiwi. (2016). Analisis Kemampuan Koneksi Matematis Siswa Kelas Viiipada Materi Teorema Pythagoras. https://publikasiilmiah.ums.ac.id/handle/11617/6978 (diakses 25 maret 2019).

Rosmaiyadi, R. (2017). Analisis Kemampuan Berpikir Kritis Matematis Siswa Dalam Learning Cycle 7e Berdasarkan Gaya Belajar. Jurnal Aksioma, 6(1), 12-19.

Rusmining, Waluya, S.B. \& Sugianto. (2014). Analysis of Mathematics Literacy, Learning Constructivism and Character Education (Case Studies on XI Class of SMK Roudlotus Saidiyyah Semarang, Indonesia)". International Journal of Education and Research, 2(8), 331340.

Sadirman. (2014). Interaksi dan Motivasi Belajar Mengajar. Jakarta: Rajawali pers.

Sari, A.N., Wahyuni, R., \& Rosmaiyadi. (2016). Penerapan Pendekatan Open-Ended untuk Meningkatkan Kemampuan Berpikir Kritis Siswa Pada Materi Aljabar Kelas VIII SMP Negeri 10 Pemangkat. Jurnal Pendidikan Matematika Indonesia, 1(1), 20-24.

Silvia. M. (2015). Analisis Motivasi Belajar Internal Siswa Program Akselerasi Kelas VIII SMP Negeri 6 Ambon. Jurnal pendidikan, 3(1), 104-115.

Siti. M. (2018). Analisis Literasi Matematika Terhadap Kemampuan Berpikir Kritis Matematika Dan Pendidikan Karakter Mandiri. Jurnal unnes, 1(1), 318-325.

Sriwijaya. (2019). Pandangan Matematika Sebagai Aktivitas Insani Beserta Dampak Pembelajarannya. Jurnal Pendidikan Matematika, 13(1), 101-118.

Sugiyono. (2017). Metode Penelitian Pendidikan. Bandung: Alfabeta.

Sunandar, Shodik. (2012). Hakekat Keaktifan Belajar. http://m4ya5a.blogspot.com/2012/05/hakikatkeaktifan-belajar.html. (diakses 28 April 2018).

Susanti. (2016). Penerapan Model Quantum Teaching dalam peningkatan Pembelajaran Matematikan tentamg Bangun Ruang Siswa Kelas V SD Negeri Mewek. Jurnal pendidikan, 4(2), 123132.

Syahrida. K. (2014). Penerapan Model Pembelajaran Quantum Teaching untuk Meningkatkan Hasil Belajar Siswa pada Sub Pokok Bahasan Faktor Persekutuan Terbesar (FPB)dan 


\section{VARIABEL $\bigcirc \begin{aligned} & \text { Variabel Vol. } 2 \text { No. } 2 \\ & \text { (October 2019). Page: 46-55 }\end{aligned}$}

KelipatanPersekutuan Terkecil (KPK) Kelas VI SD Negeri 0605856 Medan. https://www.researchgate.net/publication/320728677 (diakses 29 maret 2018).

Umi, M. (2012). Penerapan Strategi Pembelajaran Quantum Teaching Sebagai Upaya Meningkatkan Keaktifan Belajar Matematika Konsep Pecahan Pada Siswa Kelas IV SD Negeri Bangkok Kecamatan Karanggede Kabupaten Boyolali. http://eprints.ums.ac.id/21589/12/naskah_publikasi (diakses 9 febuari 2018).

Wijiyanto. (2012). Model Pembelajaran Quantum Teaching untuk Meningkatkan Motivasi Belajar IPA Bagi Siswa Kelas III SD Muhammadiyah Sambon Banyudono Boyolali. http://eprints.ums.ac.id/20031(diakses 3 januari 2018).

Wiwin. (2018). Penerapan Model Quantum Teaching Untuk Meningkatkan Hasil Belajar Matematika Materi Pecahan Pada Siswa Kelas VII SMP Negeri 3 Getasan. Jurnal Mitra Pendidikan, 2(1), 148-159.

Yunus, A. Tita, M. Hana, Y. (2017). Pembelajaran Literasi. Jakarta: Bumi Aksa. 